\title{
Body as Architecture: Designing the Stout Body in the Age of Standardization
}

By Lauren Downing Peters
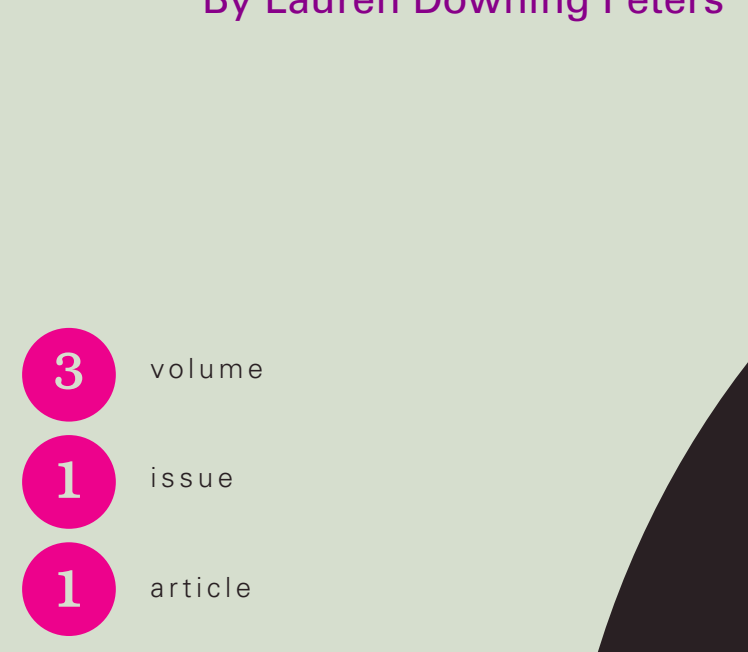

KEYWORDS:

PLUS-SIZE

STOUTWEAR

ARCHITECTURE

\section{DESIGN}

FASHION DESIGN DISCOURSE 
INTRODUCTION

\section{In her 1924 advice manual, Style and the Woman, home economist Marie Cary prof- fered fashion advice to American women who struggled to navigate the nation's rapidly changing consumer landscape.}

Up until the late nineteenth century, women had either relied upon dressmakers or their own faculties as home sewers to build modest wardrobes; however, with the emergence of the modern department store and catalog consumerism, women increasingly had a profusion of ready-made options at their fingertips. This sheer abundance of choice, Cary argued, had resulted in a "crisis in style." ${ }^{1}$ Women, she wrote, were increasingly being made fashion victims as they selected rather than made their clothes. Her book Style and the Woman was therefore conceived to help women "purchase with confidence." 2 With chapters dedicated to each type of American woman from the athletic type to the petite, elfin type - Cary tailored her advice to suit the sartorial needs and lifestyles of a diverse readership.

While Cary argued that each of the various female types had certain tendencies that needed to be overcome in the pursuit of style, she gave extra consideration to the sartorial plight of the so-called "stout" woman with no fewer than five chapters dedicated to those who tended toward "overweight." 3 Of all the female types, Cary argued that the stout woman faced the greatest obstacles in achieving a modish appearance. In an era in which hemlines were rising, silhouettes were becoming physically less constraining, and the feminine beauty 
ideal was becoming more youthful, Cary believed that the stout woman's generous curves placed her distinctly at odds with the rationalized, streamlined aesthetics of modernity. ${ }^{4}$ Cary's advice for the stout woman therefore largely revolved around reducing the stout woman's overall size and concealing her many points of corporeal contention through dress. ${ }^{5}$

Rather than bright colors, Cary wrote that stout women should familiarize themselves with palettes of grey, black, and blue. Instead of noisy, voluminous fabrics like taffeta and chiffon, Cary suggested her stout readers gravitate toward quieter wool and flannel suiting, and avoid attention-grabbing trimmings and accessories. Rather than the heights of fashion, Cary argued that the stout woman should aspire to simply fit in. ${ }^{6}$ In pursuing this notion, however, Cary spent an inordinate number of words offering suggestions for how the stout woman could diminish her size through the artful application of camouflage within her own home. Within these passages, the curious relationship between stoutwear and architecture begins to present itself:

The secret of looking comely in the kitchen is to wear a dress that harmonizes with the texture and color of the room, as well as with the wearer. The texture of percale, chambray, gingham, and cotton crepe harmonize with the painted walls and enameled woodwork of the kitchen. $^{7}$

A little later in the volume, Cary shifted registers to speak to the stout woman who does not do her own cooking, explaining:

If she... directs her household from the living room, she must choose her dress of a color that harmonizes with that room. But she must be careful never to wear a dress of the same color as the largest expanse of color in the background. For instance, if her favorite spot is the corner of a maroon velvet davenport, she could not sit on it in a maroon dress, or there would be no limit to her size. To avoid looking spread out she would choose a harmonious color, but one enough different to allow her a defining line against the davenport. ${ }^{8}$ 


\section{Within passages such as these, Cary draws uncomfortable parallels between interior ar- chitecture, the stout woman's generous size, and the tensions between "social" and "phys- ical" camouflage that manifested in much fashion advice writing during this period. ${ }^{9}$}

In doing so, she underscores the notion that the stout woman's place is within the comfortable confines of her home in which she could effectively camouflage her size amid the architectures and trappings of middle class domesticity. In her attempt to offer the stout woman helpful advice, however, Cary perhaps unwittingly taps into what can only be described as a growing resentment toward and mistrust of the fat body during this period.

In his book Fat History (1997), Peter Stearns outlines the factors that led to the emergence of modern fat stigma in the United States in the early twentieth-century, and how women's bodies, in particular, were caught in its crosshairs. Among them: shifting beauty standards defined by youth and slenderness, changing notions of success, urbanization, new definitions of illness, and different ways of assessing self-worth. ${ }^{10}$ A particular source of anxiety, however, stemmed from concerns over women's increasingly leisured lifestyles, facilitated by new technologies such as the electric vacuum cleaner and the automobile. ${ }^{11}$ Within this context, stout women had come to be perceived as not only unfashionable, but literally out of harmony with the architectures of modern life. Indeed, as Cary's labels for the different types of stout women suggest, such as the "home type" and the "comfortable type," hers was a body that was more fit for the domestic sphere than for public life. Although Cary's discussions about how the stout woman should choose her clothing so as to better blend into her surroundings are a spectacular instance, the intersections between stoutwear and the architectures of modernity were numerous within early twentieth-century fashion design discourses.

With Cary's advice manual serving as a fruitful, if somewhat confounding, starting point, this article considers the $\mathrm{cu}^{-}$ rious intersections of the stoutwear design, architectural discourse, and Gestalt Psychology in early twentieth-century fashion media. Drawing upon Michel Foucault's insight that discourses are not merely "slender surfaces of contact" but "systematically form the objects of which they speak"12 as well as Joanne Entwistle's contention that conventions of dress make the body "appropriate, acceptable and indeed respectable or possibly even desirable,"13 this 
article rethinks the biological determinism of modern obesity discourse and argues that the stout body was constructed in and through design discourse and specifically through attempts to control and contain it. This research therefore underscores the idea that the fashion media is a meaningful and productive site in which in which bodies are contested, constructed and, perhaps most importantly, known.

\section{THE STOUT BODY IN THE AGE OF STANDARDIZATION}

Within the longer history of the ready-to-wear industry in the United States, which began in earnest in the mid-nineteenth century, ${ }^{14}$ the category of "stoutwear" was a relative latecomer. While "stout" corsets and underwear could be purchased as early as $1896,{ }^{15}$ stoutwear wouldn't be recognized as an apparel category until 1915 when Women's Wear anticipated that stoutwear was primed to become one of the ready-to-wear industry's most profitable apparel categories. ${ }^{16}$ In articles such as this, profit-hungry manufacturers and retailers explained to the trade journal's readership how you "haven't any idea how many fat women there are until you begin to sell something they want."17 In an illustration accompanying the article (Figure 1), an endless sea of stout consumers is rendered in larger-than-life proportions, dwarfing the adjacent buildings. While on the one hand, the illustration emphasized the idea that there was a viable market for stoutwear, on the other, it also tapped into America's growing anxieties around weight during this period. Specifically, it visualized deep-seated prejudices about the degree to which fat women did not fit into a rapidly modernizing society. 


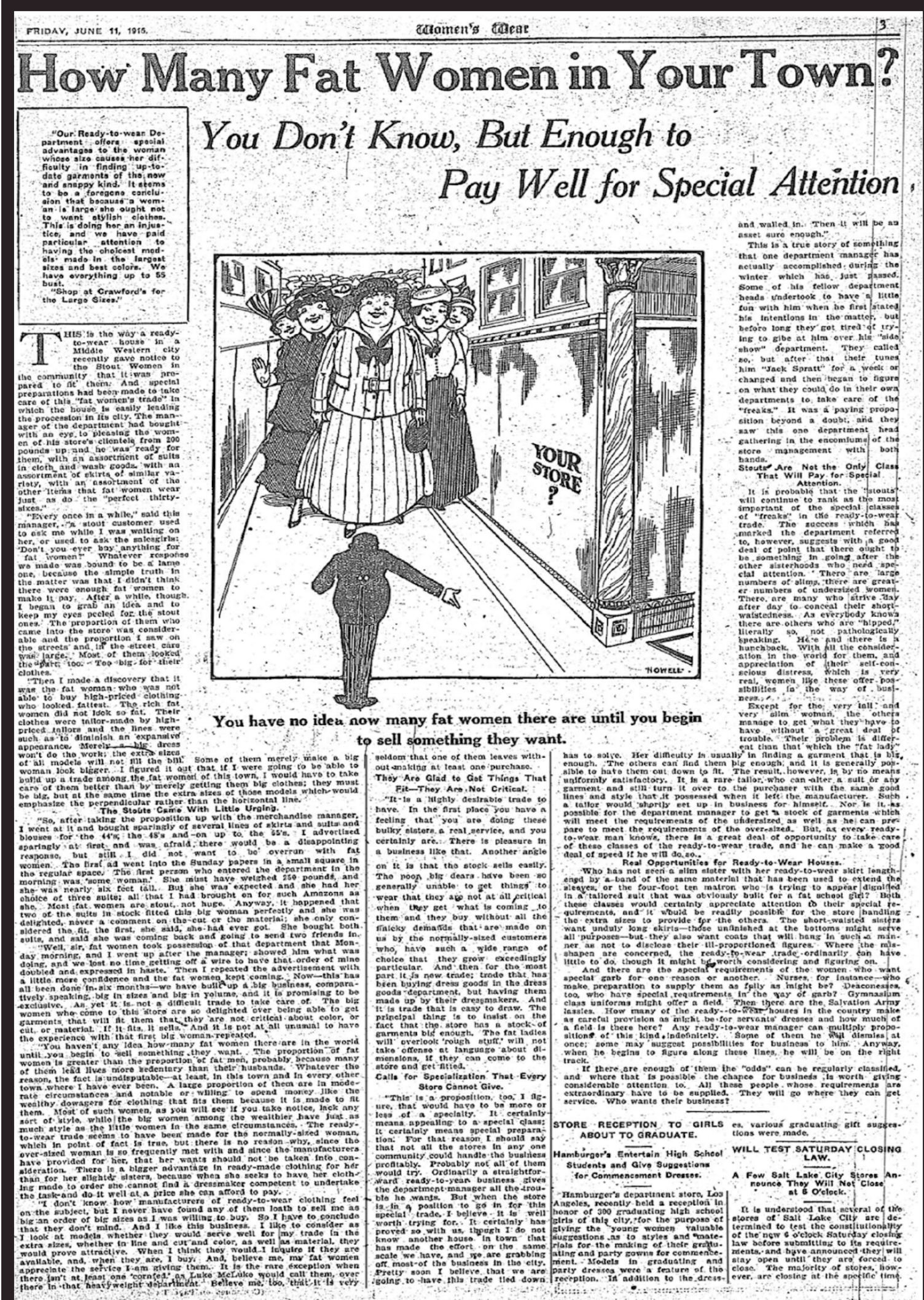


As the nation hurtled toward greater mechanization and standardization, Americans took delight in carnival freak shows at which they could gawk at figures like Brooklyn's 685-pound fat lady Jolly Mabel, who was reported in The New York Times to have had a "booming" laugh that shook Manhattan's skyscrapers. ${ }^{18}$ Contradictorily, fat women enthralled the public while also provoking its disgust, evidencing the particularly women-focused tenor of early twentieth-century fat stigma. ${ }^{19}$ The media was therefore littered with grotesque depictions of fat embodiment that forcefully underscored the idea that fat women, literally and figuratively, did not fit in. Vogue's own "Woman of Generous Proportions" was one who could not fit into the cabins of newer, sportier automobiles (Figure 2). In the trade press, the stout woman was derogatorily referred to as a "freak" among "normal" women. ${ }^{20} \mathrm{~W}$ ith the ascendance of the slender, youthful ideal, the stout woman had become a grotesque caricature of femininity, or, as one Vogue correspondent more euphemistically wrote, the fat woman's body was "a soft solace in a world of sharp curves." 21

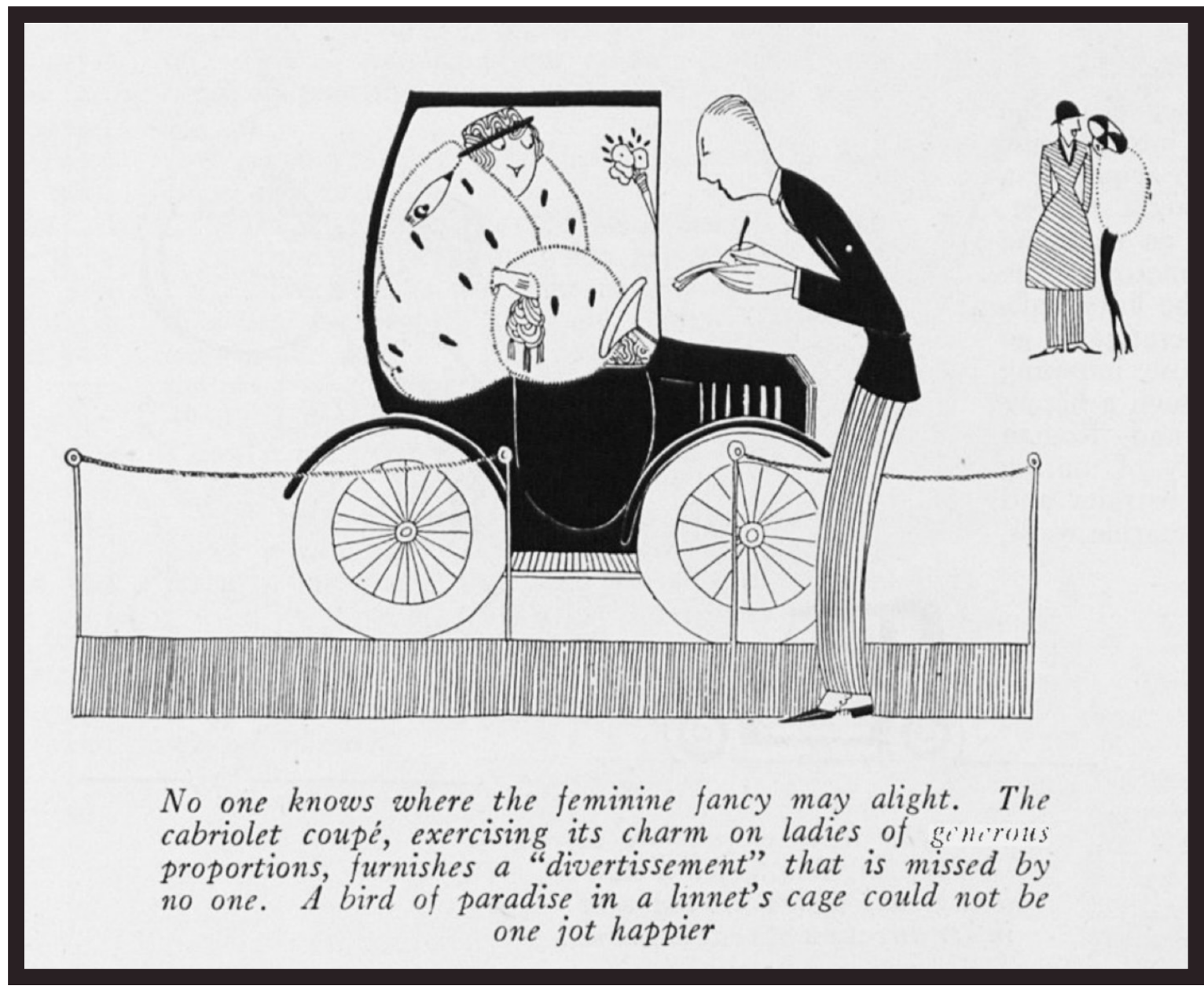

FIGURE 2 Detail from "London Ladies and Landaulets," Vogue (January 1, 1920), 64. 
Her perceived deviations from the normative body were amplified by the emergent technology of standardized sizing. While the origins of standardized sizing can be located in the eighteenth century, and specifically in Europe where wars and colonial unrest resulted in the formation of large standing armies that required a vast amount of standardized uniforms, ${ }^{22}$ American tailors perfected the practice in the mid-nineteenth century, making standardization viable on a mass scale. ${ }^{23} \mathrm{How}^{-}$ ever, standardized sizing systems would only really fall into wide use in the late nineteenth century amid the rise of catalog consumerism. During this period, both Sears Roebuck \& Co. and Montgomery Ward \& Co. boasted about their ability to fit every body. ${ }^{24}$ Although the technology of standardized sizing enabled what some regard as the "democratization" of dress in the United States in the early twentieth-century, ${ }^{25}$ it would have repercussions far beyond how people purchased clothing.

\section{Indeed, it would dramatically alter the ways about which the "normal" body was thought.}

As accounting scholar Ingrid Jeacle has written, standardized sizing creates categories of bodies by assigning a statistically-generated number to every human form. ${ }^{26}$ Sizing may therefore be understood as an exemplary Foucauldian technology of the body - one that functions as a control technique that creates docile, disciplined bodies, and which affects the ways about which "deviance" and "normalcy" are thought. ${ }^{27}$ In the late nineteenth century, the largest standard sizes topped out at a size $40 .{ }^{28}$ Bodies that fell outside that narrow range were thereby rendered non-standard and, importantly, too large to participate in an essential experience of modernity: buying clothing "off-the-rack." While Sears Roebuck \& Co. offered a broad range of ready-made garments in standard sizes as early as 1902, "very tall or very stout" women, along with those who were "particularly hard to fit for any reason," had to rely upon the services of a mail-order custom tailoring department at an extra 
expense. ${ }^{29}$ In spite of the growing sophistication of mass manufacturing technologies, stout women, it seems, continued to be plagued by lack of choice and improper fits well into the second decade of the twentieth century. Indeed, as an article published in Women's Wear in 1915 observed, stout women were being "driven ... from the store to the dressmaker" and often had to wait "10 days or two weeks while it is being remade." 30 Rather than relying upon mass manufactured options, the trade publication therefore suggested that the stout woman "might just as well continue with her dressmaker."31 A 1917 article published in the New York Times titled "Stout Women Can Now Be Stylish" echoed this point, writing about how the stout woman was not having her wants met through "regular channels, but in a way that often entailed annoying delays, tedious fittings and high prices." 32 Thus, even as American manufacturers perfected the practice of mass manufacturing, stout women still largely had to have their clothing custom fit by their tailors and dressmakers. Yet, with an estimated one-third of the population classifying as stout according to height and weight tables that were being constructed by actuaries and physicians during this period, ${ }^{33}$ some pioneering manufacturers quickly realized that there was a lucrative business opportunity to be had in solving the problem of fitting the fat body.

Early stoutwear entrepreneurs many of whom had no particular pedigree in fashion design - seized on this fact. Among them, mechanical engineer Albert
Malsin noted the rampant problems in fit in mass manufactured garments, especially for larger women. As was reported within the fashion media at the time, Malsin designed and conducted a survey of over 3,000 stout women with the goal of improving upon the standardized sizing system. ${ }^{34}$ From this survey, he concluded that the practice of grading garments up from a standard median size 36 was inherently flawed given the irregularity with which the body deposits fat. In order to accommodate the what he described as the "especially irregular" bodies of stout women, he therefore conceived of a three-part sizing system for the "full-busted," "stout all over," and "flat busted" types of stout women. ${ }^{35}$

While Malsin was first and foremost preoccupied with resolving the problem of poor fits in mass produced clothing, his writing also evidenced a preoccupation with the science of aesthetics that would ultimately eclipse his initial concerns about fit alone. In articles published across the trade media, Malsin touted his scientific design philosophy, which held that makers of large-size dresses had long neglected "certain well-known scientific laws" 36 and had rendered the stout woman's dress too plainly. This had the result, he argued, of merely making her appear broader and shorter. In addition to solving problems in fit, Malsin therefore argued that designers of stoutwear should look to an unlikely place in conceiving of ways to effect the appearance of bodily slenderness. That place was to the principles of High Gothic architecture. 


\section{BUILDING A BETTER STOUT BODY}

In April of 1916, Albert Malsin expounded on his architecturally-inflected fashion design philosophy in the pages of the Richmond Times-Dispatch over the course of four weeks. In the first of these front-page articles, Malsin introduced himself and described his particular qualifications for making clothing for stout women in the following manner:

I am a mechanical engineer, but instead of designing dynamos or making machinery, I specialize in the design and construction of clothes for stout women.

Doubtless you will think this is a very extraordinary combination. Probably you will be unable to see what connection there can possibly be between engineering and the clothing of a woman whose bust, or waist line, or hips are all out of proportion to the rest of her body. As a matter of fact the two things have a great deal in common. Had I not been trained in engineering and familiar with a number of other scientific branches I should never have been able to do what I have done toward making it possible for stout women to secure clothes that not only fit but make them look less stout....

And before you go very far into what I have to say you will agree with me that stout women would have been immeasurably better off in health, peace of mind and good looks if the making of their clothes had been put on a scientific basis long ago ${ }^{37}$

Although Malsin's entryway into stoutwear was via his wife Lena Himmelstein Bryant who, by herself and prior to marrying Malsin had already nurtured a successful maternity wear business into being, ${ }^{38}$ in this lengthy passage none of that background information is deemed worth mentioning. Rather, Malsin's pedigree in engineering is framed as a sufficient prerequisite for designing stoutwear - a practice that, which he goes onto explain, lies at the intersection of "physics, mathematics, optics, psychology, and other scientific branches," but notably not fashion design. Indeed, in this same article Malsin suggested that fashion design invoked "too little science, too much haphazard guess work and rule of thumb." 39 
In devising a more precise approach to designing for the stout woman, Malsin's key insight was that stoutwear garments had been improperly graded on the proportional foundation of the normative body and thus the stout woman's sartorial frustrations, above all else, emerged from inconsistent and poor garment fits. At the same time, however, Malsin believed that the stout woman's clothes tended to make her "look stout" due to the carelessness with which they were designed. What, however, did it mean for a garment to make a stout woman "look" stout? According to Malsin, "A woman's height should be seven times the height of her head," yet stoutwear manufacturers had, by-and-large, failed to acknowledge or respect these universal "laws of growth of the human body ... and their ramifications," and had thus created garments that only exacerbated the stout woman's size rather than striving toward creating "an impression of height" in approximating this bodily ideal. ${ }^{40}$

To "flatter" the figure was to therefore create the appearance of a body that approximated this ideal by designing garments that visibly compensated for and corrected the stout woman's "odd" proportions. In other words, height was seen as a remedy for stoutness. This, as Malsin told the Oregon Daily Journal in 1916, was a design practice "built on the idea of aspiration" toward height, but more importantly, toward slenderness. ${ }^{41}$ By this logic, and according to Malsin, there existed an inherently "correct" or "true" way to design clothes in order to meet these "aspirational" ends. Failed designs, however, were not the result of improper patterns or inappropriate colors; rather, Malsin argued that they had not been designed on so-called "scientific lines."

In the second article in the series, Malsin discussed this precept in much greater detail and, notably, if not curiously, did so by invoking architectural jargon:

The architect knows how to arrange his materials so as to give even a very large building an effect of airy grace, height and slenderness.

I can think of nothing better for the designer of clothing for stout people to keep constantly in mind than one of the great Gothic cathedrals. Aspiration, the reaching for something higher, is the fundamental principal of Gothic architecture, and every line from the cornerstone to the topmost peak of the spire is designed and constructed with this effect in view.

It is exactly the same effect which stout women must constantly strive for in their clothes. ${ }^{42}$

The above quotation is notable for a number of reasons - not least of which being Malsin's suggestion that women, but also presumably designers, should "constantly strive" for achieving the appearance of 
height through stoutwear, or a notion which thereby presumed that all stout women inherently desired to look more slender. To the point of architecture, however, here Malsin draws one of the clearest parallels between garment design and architectural practice, arguing that stoutwear manufacturers should always keep in mind the "great Gothic cathedrals" and the sense of "airy grace" and weightlessness created by their soaring lines. Continuing, he explained how, "with the right lines rightly applied, [the stout woman] can create as deceptive an illusion of height and slenderness as the architect does with his huge structures of brick and stone." 43

\section{By applying certain architectural principles to the art and science of dress design, Malsin believed that he could effectively build a better stout body- one more aligned with the youth- fully slender ideal that was in ascendance.}

To demonstrate his design theories, in one of the Richmond Times-Dispatch features Malsin included a series of schematic renderings to show how these principles could be put into practice (Figure 3). In each of the two figures, a woman is depicted on the far left in a dress that, in Malsin's words, makes her appear 'stouter' than ever in a plain, unadorned gown." In the successive illustrations, however, Malsin applied to the same dress "vertical and slanting lines, pointed panels, broken belt line[s], curved bodies, etc." according to "scientific principles" in order to create an appearance of greater slenderness. In the second illustration, Malsin also emphasizes how "breaking the ugly horizontal lines of the belt and the lower coat" can effect a "pleasing transformation" of the stout woman's body. The transformative powers of these principles, however, reached their zenith in a photograph of a stout woman, over whom an illustrated dress had been superimposed, and which figured centrally in the full-page spread (Figure 4). 
FIGURE 3 Detail from "How Science is Helping 'Stout' People to Look Less 'Stout,'" Richmond Times-Dispatch (April 16, 1916), 54.

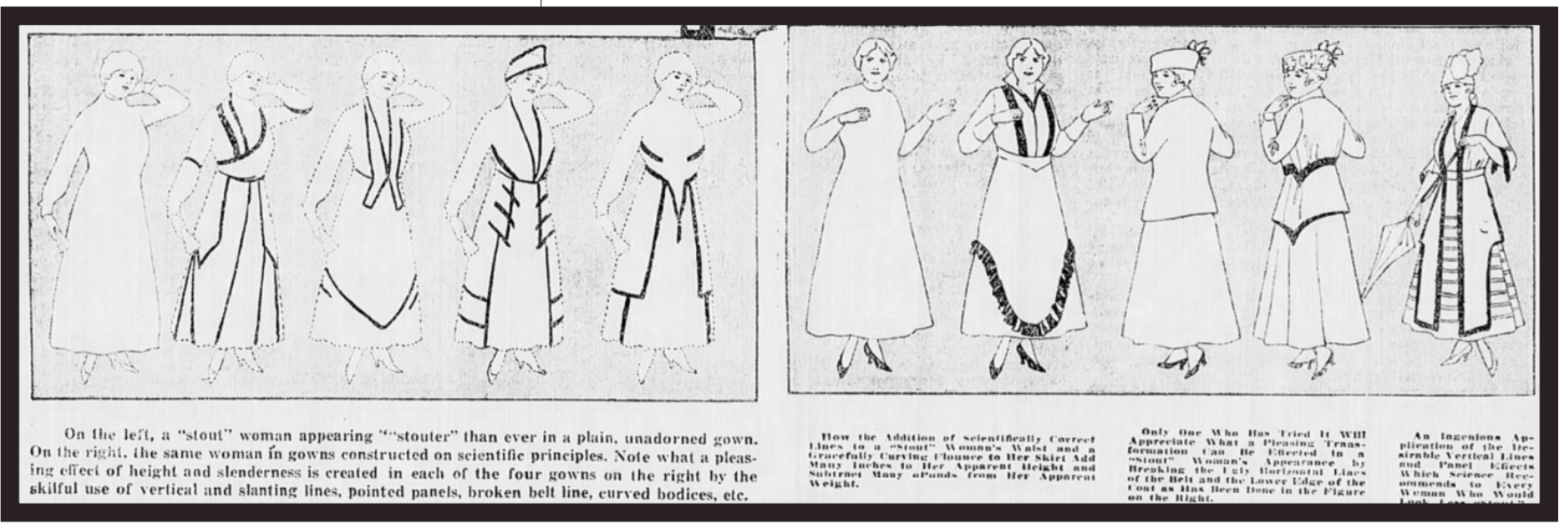

How Science is Melping "Stout"People to Look Surprising Illusion of Height and Slenderness

That Can Be Given

Men and Women of Too

Generous Proportions by a

Skilful Arrangement of

the "Lines" of Their Clothes

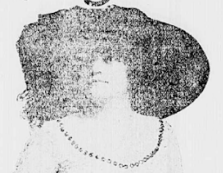

Less "Stout"

$T$

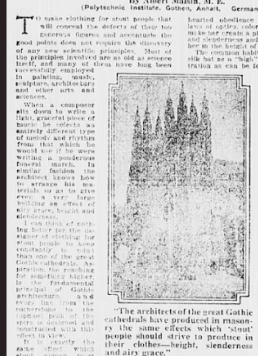

ris.
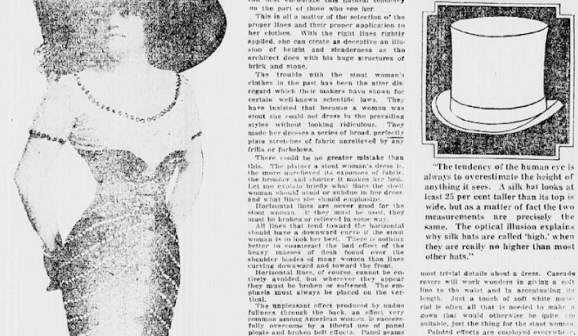

$=-5$

$=-1=$

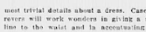
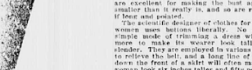

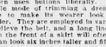
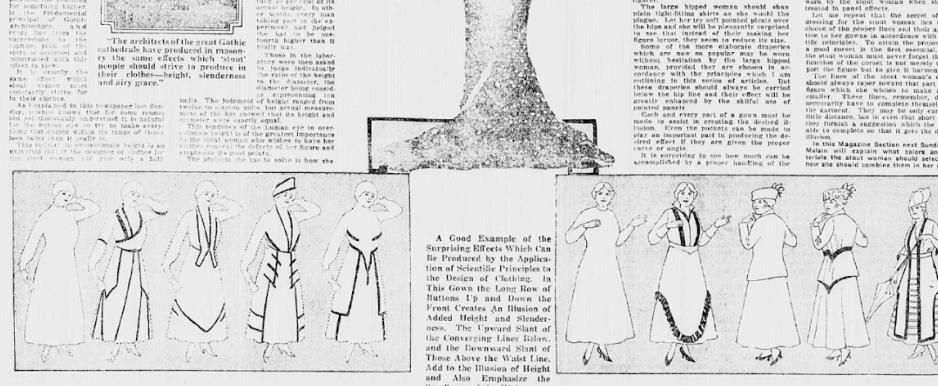

$=-5=$

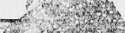

.

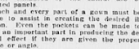
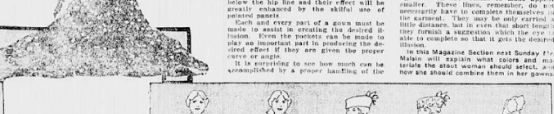

(i)

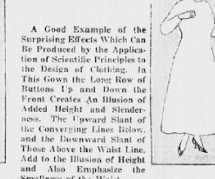

i)

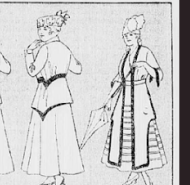

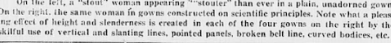

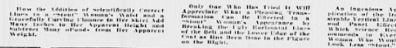

N=

Just

\section{0}
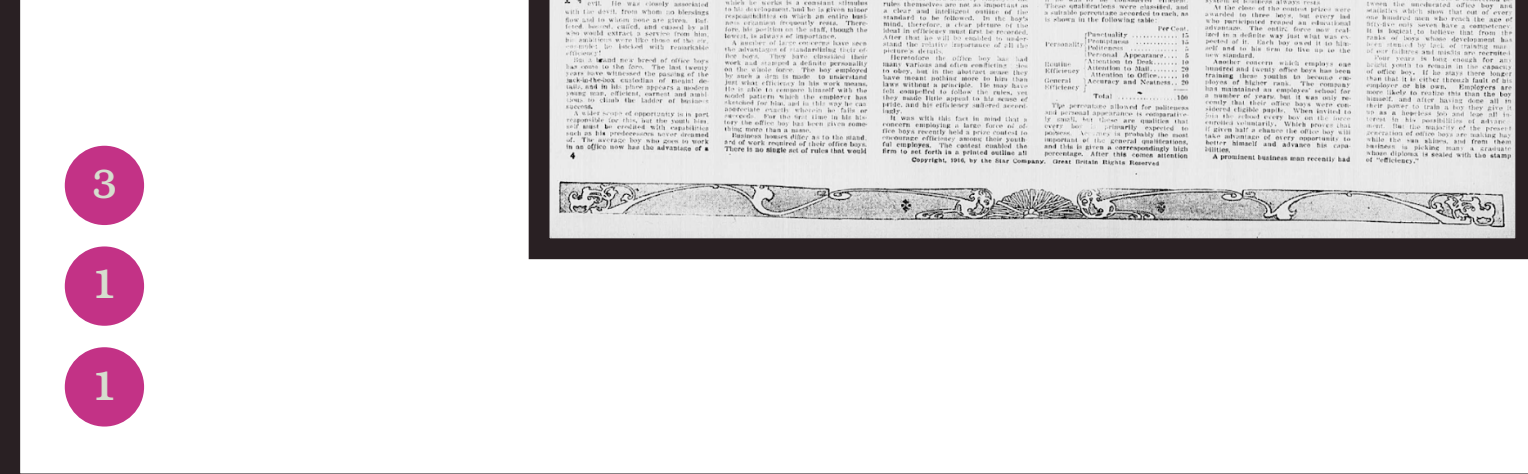

FIGURE 4 "How Science

is Helping 'Stout' People to Look Less 'Stout,'" Richmond Times-Dispatch (April 16, 1916), 54. 
According to Malsin, the gown - with its tightly-nipped waist and flared hem that together create an exaggerated wasp-waisted silhouette — represents "a good example of the surprising effects which can be produced by the application of scientific principles to the design of clothing." Specifically, the rows of buttons, according to Malsin, created "an illusion of added height and slenderness" while emphasizing "the smallness of the waist." While elsewhere, Malsin suggested that lines could be used to variously create an appearance of height, or to minimize problematic parts of the body, through these illustrations it becomes clear that Malsin's design ambition was both singular and somewhat conservative. Indeed, the appearance of slenderness was chiefly created by exaggerating the smallness of the waistline and, perhaps more importantly, by creating a recognizably feminine hourglass shape. While Malsin suggested elsewhere that stoutness was not determined by weight but rather by a woman's "odd proportions," these illustrations nevertheless suggest that stoutness was, first and foremost, an affliction of the abdomen. ${ }^{44}$

In spite of the fact that what he was proposing was not, in fact, a radical re-visioning of the silhouette, by couching his design practices in the discourses of architecture Albert Malsin tapped into a strain of thought that Bradley Quinn has described as fashion's desire to "push forward into the cultural landscape in pursuit of the accomplished forms mastered by art and architecture." 45 By invoking the language of architecture, Malsin was therefore aligning himself with prominent modernist architects and design thinkers of the period, like Adolf Loos and Otto Wegner, who in their writings disparaged fashion as "frivolous, functional ... wasteful, the antithesis of rationality and simplicity." 46 Whereas fashion design in Malsin's writing is both explicitly and implicitly diminished as low-skilled and frivolous, the practice of constructing a silhouette, and perhaps more importantly, a silhouette that "flatters" or "changes" a figure, is rendered the more intellectual and exacting task. Here, the discourses of architecture become discourses of fashion design mastery. 


\section{On the one hand, the prevalence of architectural references within descriptions of stoutwear design practice could be written off as little more than marketing bluster. On the other, they evidence a tendency shared by male designers during this time to make competing statements, each loftier than the next, about having changed the shape of women's bodies.}

For instance, Poiret's overstated claims to have altered the course of fashion in "liberating" women from the confines of their corsets a decade earlier come to mind. ${ }^{47}$ Yet, even modernist architects dismissive of fashion - from Otto Wegner, to Henry van de Velde, to Frank Lloyd Wright were making proposals during this period for how to alter and improve upon women's dress, focusing mainly on relaxing the silhouette. This professed preoccupation with essential form (rather than surface ornamentation) formed the backbone of modern architectural and design thinking, but also clearly found resonance within the sphere of fashion design. Within this context, the silhouette became a means to intervene and improve upon the natural and inherently flawed body where the supposed superficiality fashion was believed to have otherwise failed. By invoking these discourses, stoutwear manufacturers thereby became architects not only of garments, but of the body itself. Albert Malsin, however, was not the only designer to invoke the discourses of architecture within the context of stoutwear design and manufacturing, nor was he alone in his ambition to build a better stout body. 
In a 1915 Women's Wear article, for instance, two stoutwear manufacturers from the New Yorkbased firm Bernstein, Baum, Cravis \& Co. were asked, "How do you get your styles?"48 In their response, they explained how from one "good model" they could derive "six or seven suits." The key, according to the manufacturers, lies in first finding the "right outline" in a suit or dress, after which, "little feminine touches" can be added - a practice which the two argued was best left in the hands of women. Continuing, they suggest that while the subject of decoration has always "troubled" tailors, for "men rarely understand it," women "go to it intuitively and naturally." While in this quotation the manufacturers at once elevate women's work, arguing that it is those "final touches [that] always make or mar a suit," they also establish a gendered design dichotomy that equated garment design or, the "right outline of a tailored suit or dress" (i.e. the silhouette) - with the masculine field of architecture and the superficial work of fashion design or "decoration" with women and domesticity.

The sentiments of the manufacturers from Bernstein, Baum, Cravis \& Co. found their visual corollary in an advertisement for the New Yorkbased stoutwear firm Baum \& Wolff. Inc., which ran in the January 1918 edition of The Dry Goods Economist(Figure 5). Featuring a pen-and-ink illustration of a towering stout woman (a visual means of representing stout woman as literally larger than life that had by this time become something of a visual cliché) around whom four comparatively diminutive men, donning white artist smocks, gather upon scaffolding to put the finishing touches on her black dress. The accompanying advertising copy reads:

Camouflage.

That's the stout dress problem! Make a stout figure appear slim — a curved line straight!

It's just "knowing" that makes our designs flatter the stout figure. Baum \& Wolff models don't just fit the figure - they flatter it - change it - give it the youthfulness it needs to answer to style.

Every new silhouette is in Baum \& Wolff models - not just "put" there, but built into each model with a thorough knowledge of the stout figure and its needs. ${ }^{49}$

Although perhaps less forceful than the above quotation from the manufacturers at Bernstein, Baum \& Cravis who correlate the work of the designer to that of the architect, the legitimizing discourses of architecture, and specifically of "building" a better body, are here invoked as a means to elevate the practice of stoutwear design to something higher than "mere" dress making or fashion design. 


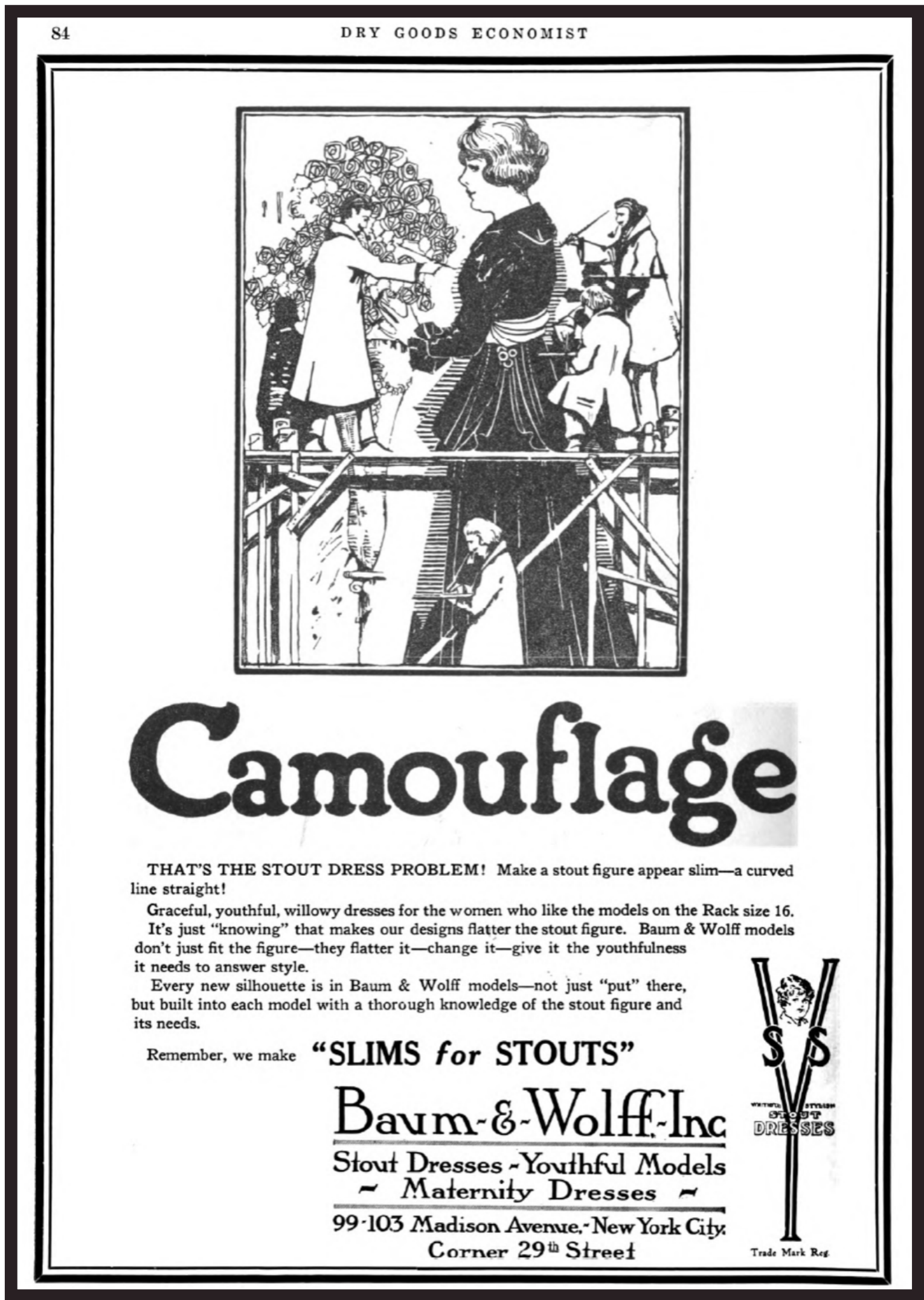


As Nancy Troy, Ilya Parkins, Jennifer Craik, and Christopher Breward have all observed, male couturiers from Charles Frederick Worth to the aforementioned Paul Poiret had long made claims about variously reinventing the fashionable silhouette or as a means of elevating themselves as singular design geniuses. ${ }^{50}$ Unlike the great couturiers, however, American stoutwear manufacturers were decidedly more embedded in the market, not only as makers of mass-produced clothing but as makers of mass produced ideals. Stoutwear designers and manufacturers, however, were not content to merely draw upon architectural jargon in framing themselves as designers of both bodies and garments. Indeed, sophisticated theories of visual perception, borrowed largely from the field of Gestalt Psychology and the European avant-garde, would also find their way into stoutwear design discourse.

\section{CAMOUFLAGING EXCESS}

In the 1920s, the architectural bent of stoutwear design discourse would be eclipsed by a new focus on the tenets of optical illusion derived from the writings of the Gestalt Psychologists and of the European avant-garde.

\section{Within this context, the stout woman's dress - and specifically the modish tubular silhouette - became a modernist canvas upon which stoutwear designers could test various optical theories.}

Stoutwear manufacturers' reliance upon these somewhat obscure theories underscores Elizabeth Wilson's insight that, during this period, fashion designers were deeply inspired by the modernist rejection of naturalism and the corollary notion that "a painting was just that: a flat representation, not a three-dimensional reflection of the 'real."'51 In their embrace of modernist flatness, stoutwear manufacturers therefore shifted their focus evermore toward creating the mere appearance of slenderness through dress rather than relying upon increasingly outmoded techniques of physically reshaping the body through stiff corsetry.

In a demonstration of these concepts, a twelve-part series of instructive articles titled "Selling the Customer Smartness Through Basic Art Principles” by Carl N. Werntz, an instructor at the Chicago Academy of Fine Arts, explained how:

lines, regardless of what they may do in making a dress well fitted, fashionable, properly cut or practically constructed, have an effect on our seeing organ (our eyes) which is transmitted to our minds, giving us — regardless of their special meaning a pleasant sensation or an unpleasant one. ${ }^{52}$ 
The stated aim of the twelve-part series was to delimit the so-called "psychology of line," and to unravel the popular notion that there was a single "good line" upon which all dresses should be built. However, Werntz, much like his contemporaries, was mainly a proponent of the idea that dresses - especially for the stout - should be designed with the aim of creating a "pleasant sensation" in the eyes of those who encountered her. ${ }^{53}$

While he discussed the precept of dressing well in more universal terms in the first few articles of the series, in the fifth and sixth installments Werntz went into greater detail about the psychological principles underlying what made a line "good" versus what made a line "bad." In a diagram that featured prominently in the fifth article titled "Adapting a Model to Different Figures," Werntz introduced the Müller-Lyer illusion, conceived within the field of Gestalt Psychology, which explained how line segments of equal length can be made to look shorter or longer depending upon which way the arrowheads appearing at either end of the line segment are facing (Figure 6). ${ }^{54}$ Within the realm of fashion design, he argued that this principle could be fruitfully applied to "adapt selected models to suit abnormal figures." 55 In the following week's feature, Werntz further argued that the illusion, while little understood, had long been used by dressmakers to adapt dresses for "normal figures," but could specifically "do much for the heavy figure to add apparent height and correct unbecoming proportions." 56 Continuing, Werntz further speculated on what made the stout figure so "unbecoming," describing it as an abomination of "artistic" lines:

What we call the over-heavy figure is much admired by some nations. We find such a figure artistically undesirable, because its lines are obvious - unquestionably bulging and round. To correct this, it is necessary to have the uprightness and strength of the lines rather obvious in a dress for this figure. The correct lines of a dress should then be more noticeable than the inartistic lines of the figure. A single wide, straight line is perhaps too obvious rather than on the side of subtlety. Be sure, above all else, not to let the dress of the fat woman be tight. ${ }^{57}$

In an accompanying illustration, Werntz showed how straight, long, and "strong" lines when applied to a stout woman's dress bore the capacity to "correct the unpleasant visible effect of her sagging tissues." 


\section{$\bullet \bullet \bullet \bullet \bullet \bullet \bullet \bullet \bullet \bullet \bullet \bullet \bullet \bullet \bullet \bullet \bullet \bullet \bullet \bullet \bullet \bullet \bullet \bullet \bullet \bullet \bullet \bullet \bullet \bullet \bullet \bullet \bullet \bullet \bullet \bullet \bullet \bullet \bullet \bullet \bullet \bullet \bullet \bullet \bullet \bullet \bullet \bullet \bullet \bullet \bullet \bullet \bullet \bullet \bullet \bullet \bullet \bullet \bullet \bullet \bullet \bullet \bullet \bullet \bullet \bullet \bullet \bullet \bullet \bullet \bullet \bullet \bullet \bullet$ \\ ? \\ Selling the Customer Smartness Through Basic Art Principles \\ 울 \\ $\bullet \bullet \bullet \bullet \bullet \bullet \bullet \bullet \bullet \bullet \bullet \bullet \bullet \bullet \bullet \bullet \bullet \bullet \bullet \bullet \bullet \bullet \bullet \bullet \bullet \bullet \bullet \bullet \bullet \bullet \bullet \bullet \bullet \bullet \bullet \bullet \bullet \bullet \bullet \bullet \bullet \bullet \bullet \bullet \bullet \bullet \bullet \bullet \bullet \bullet \bullet \bullet \bullet \bullet \bullet \bullet \bullet \bullet \bullet \bullet \bullet \bullet \bullet \bullet \bullet \bullet \bullet \bullet \bullet \bullet \bullet \bullet \bullet \bullet \bullet \mid$}

Illustrated Demonstrations on Charm and Artistry in Appearance Related to the Problems of Manufacturers, Buyers and Salespersons

Originated and Copyrighted by CARL N. WERnTZ;

Director the Chicago Academy Fine Arto

\section{NO. 5 ADAPTING A MODEL TO DIFFERENT FIGURES}

DO THE vertical lines (D and E) at the sides of the pleture soem to be of different length?

You know they are the same, of course, but though I have seen this drawing for years, "E" still looks the shorter.

Through this simple diagram I will show you a principle in the psychology of line-that is, the general effect lines have upon the brain when their forms are transmitted through the nerves of the eye-which is one of the most Important bastc principles of appearance. Besides being of use in designing new gowns to suit normal flgures to best advantage, it is of wonderful, help in adapting selected models to suit abnormal figures.

Carefully examine the little diagrams referred to. Notlce that the vertical line of $D$ seems much longer than that of E. Measure and you will find they are just the same. This, of course, is the old optical ilJusion.

When applied to ralment, this simple dagram shows you the only sure way of making the short woman seem taller, the tall woman less noticeable, the fat woman less wide and the thin woman seem to have a plumper figure.

To be sure you understand this valuable appearance ald, experiment on tracings of these figures as you were requested in the previous ledcon on akotching.

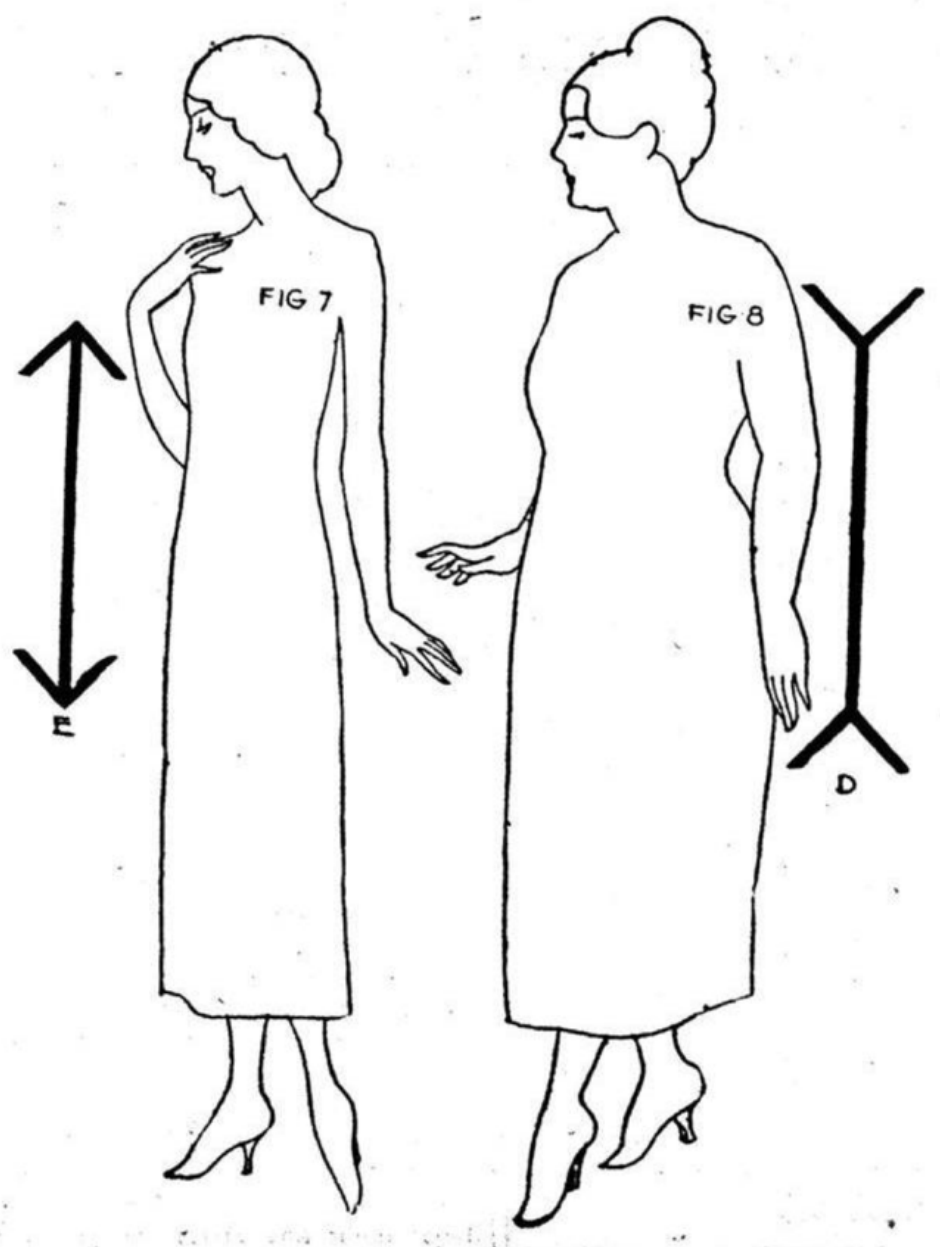


Throughout the series, Werntz vividly illustrated how fatness had come to be regarded as an abomination of modernity and, specifically, of the modernist body. As with the above examples, here the stout body is defined both by what it lacks as much as by its very abundance. This manifested in the visceral language he used to describe, on the one hand, dress as an expression of the modernist desire to intervene on the body and, on the other, the fleshy imperfection of the fat body. If artistic lines were "straight" and "strong," the fat, female body, on the other hand, was deemed "sagging" and "unbalanced." In spite of the desultory language with which he spoke about the fat woman's body, however, Werntz offered her a minor concession, arguing that "the artistic difference between the normal, fat and thin figures, is not entirely a matter of size," but rather could at least partially be attributed to the careless application of "weak" lines in her dress. ${ }^{58}$ By referring to the fat body as "artistically undesirable," Werntz did not, however, speak to an eternal or absolute conception of beauty - even has he furthered the notion that there was a "correct" way to design dresses - but rather to the modernist sensibilities of mechanical simplicity, straightness, and flatness. Although Werntz - in the detail with which he investigated the applicability of optical theories to contemporary dress design — stood alone amongst those speaking about optical illusions within the practice of stoutwear design, the modernist tenor of stoutwear design discourse was not, however, unique. Indeed, optical theories spilled over in to advice writing, too.

This crossover can most clearly be glimpsed in the style guide, Dress and Look Slender (1924) written by the home economist Jane Warren Wells, who opened her popular volume with the sentiment,

There is magic in the principles of "optical illusion" and rightly applied it is a kind of magic that one can make a permanent reality. But magic is subtle. It requires skill, watchfulness and a close abiding to the rules if every "trick" is to be a success. ${ }^{59}$

In the ensuing pages, Wells explained the subtleties of the precept of dressing to look slender without engaging in a physical reduction of the flesh. Herein, Wells framed the practice as a distinctly modern one that permitted the stout woman to know how to make "every dress, every coat, every hat... give height instead of width, youth instead of matronliness [sic], slenderness and grace instead of heaviness" (emphasis in original), thereby liberating her from the oftentimes lacking options in stoutwear departments. ${ }^{60}$ 
Later in the volume, Wells described how four different optical illusions, each of which was derived from the Gestalt School, could be applied to create the straight-line silhouette demanded of stout women within fashion discourse - a practice which she juxtaposed with that of just wearing garments built on straight lines. As a means of illuminating this idea, Wells set up a fictional scenario in which a distraught stout woman expressed her frustrations with not being able to achieve a slender appearance, writing,

"I cannot understand why I look so short and dumpy," she wails despairingly. "My dress is made on perfectly straight up-anddown lines and yet I look fatter than ever." Of course she does, because instead of extending the straight-up-and-down line by a small upturned hat of some sort and an unobtrusive skirt hem, she has broken the line top and bottom and there by shortened her appearance. ${ }^{61}$

Reproducing the Müller-Lyer illusion, which Werntz had also discussed in Women's Wear, Wells demonstrated how "a straight-line effect can be either accentuated or shortened by the lines that run out from it," which in the illustration manifested in the addition of a taller hat and the application of geometric line details on the dress itself that quite literally reproduced the illusion (Figure 7). In the proceeding pages, Wells showed the similarly slenderizing effects of the Hering Illusion, invented by the psychologist Ewald Hering in 1861 and which demonstrated how straight, vertical lines can be made to bulge outwards when placed on a background of lines radiating outward; the Ponzo Illusion created by Mario Ponzo in 1911, which demonstrated how a central line could be made to be look significantly longer when flanked by longer parallel lines; and the Pogendorff Illusion, invented by Johan Poggendorff in 1860, and which showed how an expanse or line may be made to appear broken up by bisecting it with vertical lines. Quite interestingly, within each of these illustrations, the basic silhouette of the dress changes very little; rather, Wells, not unlike her contemporaries, effectively viewed the surface of the fashionably tubular silhouette - made all the more expansive by the stout woman's non-normative proportions - as a blank canvas, ripe with potential to transform the frame without resorting to more drastic means. 
FIGURE 7

An illustration of the Müller Lyon

illusion in Jane

Warren Wells'

style guide, Dress

and Look Slender

(1924), 18-19.

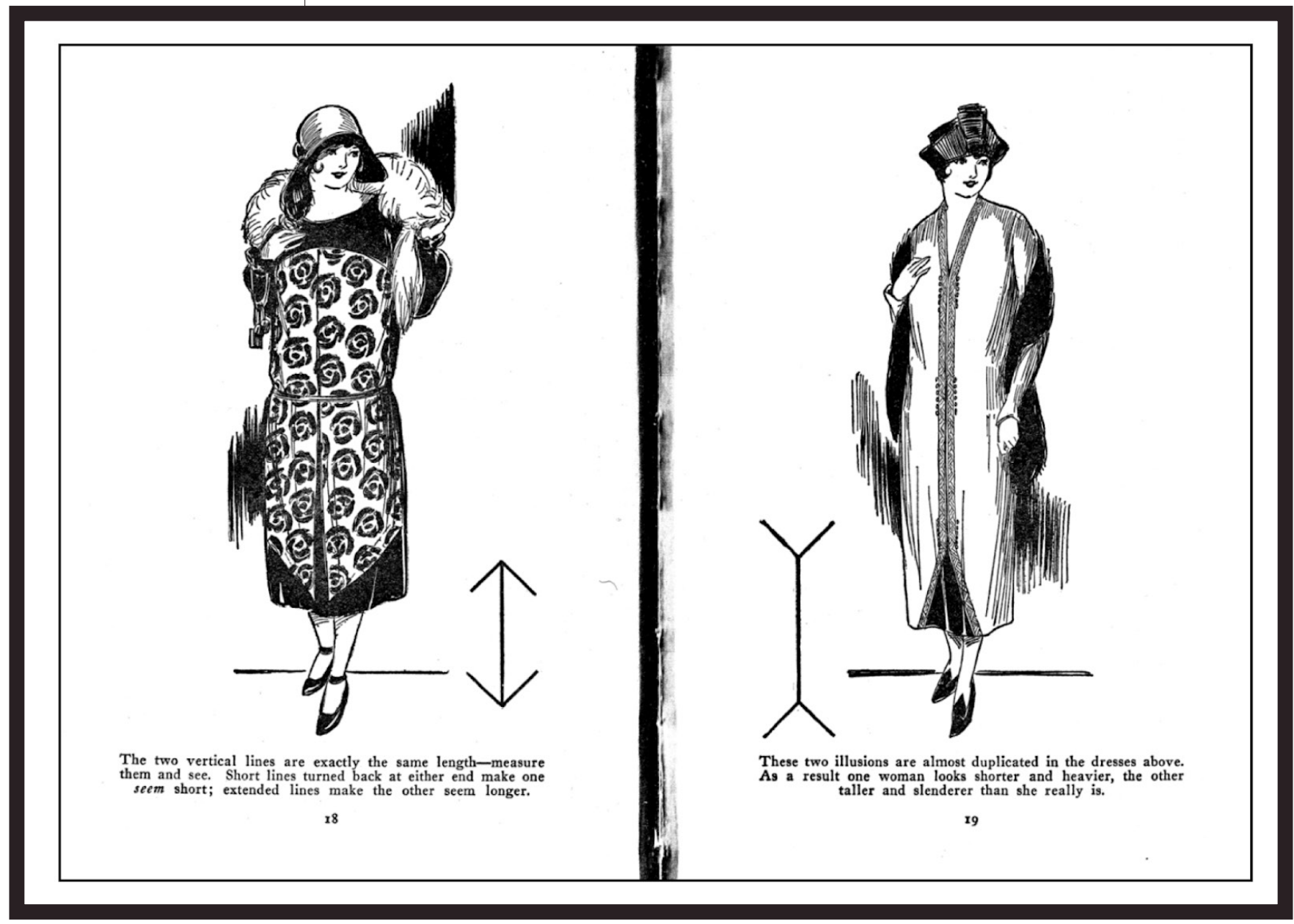

\section{CONCLUSION}

In the pursuit of building a better stout body, pleats, patterns, gussets and trimmings - or all the "frills and furbelows" of fashion design, to borrow Albert Malsin's phrasing ${ }^{62}$ - were stripped from the stout woman's dress. These surface details, as many wrote within the trade media, only served to draw attention to the stout woman's departures from the slender norm - departures that only became problems in the age of standardization and mass manufacturing. ${ }^{63}$ 


\section{In the hands of stoutwear manufacturers and advice writers, the stout woman's garments suddenly became a functional site of modernist experimentation in the pursuit of creating the appearance of all over bodily slenderness. In speaking about these new design philosophies, however, the stout woman's many points of corporeal contention were debated and discussed in great detail.}

Among them was the fact that the "sagging" and "irregular" curves of the stout woman's body were fundamentally at odds with the straight lines of modernism and, importantly, modern dress.

Within this context, architectural jargon and optical illusions were rendered tools superior to those traditionally associated with the feminine art of dressmaking. By challenging the laws of perception, designers sought to distract from fleshy bulges or errant curves that otherwise defied the logic of the standard body. In their hands, a fashionably tubular dress - with its large, unbroken expanses of fabric - was not just a way to cover up and conceal fat flesh; it was quite literally a blank canvas upon which the laws of perception could be tested in an effort to actually give the appearance of the flesh transformed. Stoutwear manufacturers' overt preoccupation with slenderizing therefore not only affected the design of stout garments, which tended to be more conservative than those created for slender women; in Foucauldian terms, the slenderizing discourses of stoutwear design also "systematically formed" what, in this era, was regarded as a stout body, while also making that body appropriate and acceptable in an increasingly fat-phobic society. 
In articles from this period, there was little consensus about where the standard body ended and where the stout body began. Oftentimes, there was significant overlap between the two. In some sources, stout sizes began at a size $36,{ }^{64}$ while other sources placed this threshold at a size $42 .{ }^{65}$ This is not to say, however, that stoutness was not clearly defined. Far more than weight and waist circumference, stoutness was constructed or "designed" within fashion design discourse through the relationship of the body to dress. Through the very act of identifying the stout body's many points of contention and "problem areas," its contours came into sharper relief. More than anything, however, stoutness - especially in articles that made claims to the stout body being "in fashion" 66 in the first decades of the twentieth century - was the product of imprecise and "unflattering" design created, as Malsin claimed, with little regard to "certain well-known scientific laws."67 Indeed, as this article has set out to demonstrate, ideas about stoutness and were produced less through concrete measurements than through attempts to contain, control, and correct the fat, female body in and through stoutwear design discourse.

At the same time designers and manufacturers were devising new and increasingly artful ways to solve the problem of the fat woman's deviant flesh - namely through modernist design discourse - one could argue that fashion, in many ways, became more accommodating of the stout body in the 1920s, both in terms of aesthetics and in terms of construction. With its straight lines and simple construction, the tubular silhouette was well suited to mass manufacturing and therefore easily adapted to fit bigger bodies. Moreover, and as is clear within stout wear design discourse, its large, unbroken expanses of fabric proved an apt canvas on which designers could experiment with various optical tricks in the pursuit creating a slender, streamlined appearance. Indeed, the rupture of the ideal silhouette and its straightening out into a more forgiving shape permitted more space, both literally and figuratively, for the stout body in fashion. With the turning over of a new decade, however, the tubular silhouette was traded for the clinging bias cut and suddenly more of the body was suddenly on display. As a result, the stout woman found herself proverbially "out of fashion" once again.

While reportage on the stoutwear industry began to dwindle as early as 1929 , in 1939 Women's Wear discontinued their special "Styles for Larger Women" section that provided weekly coverage of the goings on within the stoutwear industry, attesting to a general decline in stoutwear manufacturing during this period. Some attributed the decline in stoutwear sales nationally on an uneducated salesforce. ${ }^{68}$ Others discussed the difficulties in adapting the new decade's fashion trends - such as higher waistlines, fitted hips, and princess-cut silhouettes - to stout bodies as the more body-conscious styles of the 1930s only had the effect of making the stout woman appear, as one source commented, "somewhat conspicuous."69 Another article published in 1930 suggested, simply, that the reason the industry had begun to "atrophy" was due shifting beauty ideals mandated that it was no longer "fashionable to be fat."70 These claims, however, would prove to be 
somewhat overstated. Indeed, a number of stoutwear manufacturers continued to produce stoutwear well into the 1930s and beyond, albeit under a different name. Not least of these was Lane Bryant, which pivoted to manufacture and sell so-called "junior plenty" and "chubby" garments to teens and young women in the 1940s and 50s, and, beginning in the 1980s, plus-size garments. ${ }^{71}$

While it was never "fashionable to be fat," as some articles suggested, the fashion landscape in the United States did undergo a dramatic evolution between the 1920s and 30s, as too had the culture of beauty, weight loss, and dieting. Within this context, women could no longer expect to camouflage their corporeal flaws within the folds of the revealing, albeit generously-cut tubular dresses that were popular in the 1920s. Indeed, as Milbank writes, clothes in the 1930s "reflected leaner times," both literally and figuratively: "For the first part of the 1930s figures were almost emaciated [and therefore] clothes were narrow, long, and spare," or "simple to the extreme." 72 Within this context, and specifically with regard to fashion, fatness had gone from being a burden that could be variously hidden or re-shaped through dress, to being utterly intolerable as the rift between fat and thin grew ever wider. As the science of "obesity" was growing progressively sophisticated and as more drugs and cures emerged to combat fat, ${ }^{73}$ overweight people found themselves increasingly scrutinized, scorned, and stigmatized in the 1930s and beyond. Fashion would persist as a medium to mitigate the visible stigma of fatness; however, the modernist and comparatively hands-off preoccupation camouflage and optical illusion would be replaced by more forceful methods for effecting a slender appearance - namely, the elasticized girdle - that would again forcefully mold the fat woman's flesh into something approximating the fashionable ideal.

\section{ACKNOWLEDGEMENTS}

This article is adapted from chapters four and seven of my PhD dissertation, "Stoutwear and the Discourses of Disorder: Constructing the Fat, Female Body in American Fashion in the Age of Standardization, 1915-1930" (Centre for Fashion Studies, Stockholm University, 2018). Portions of this research was presented at the 2018 Association for Art History conference in London, UK and at the 2020 symposium, "American Everyday: Resistance, Revolution \& Transformation" in Chicago, IL. I am grateful to those who offered constrictive feedback at these conferences. 


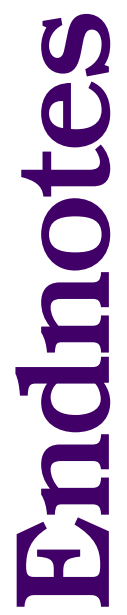

${ }^{1}$ Marie Cary, Style and the Woman (New York: The Textile Publishing Company, 1924), 2.

2 Ibid.

3 According to historic grading tables, stout sizes began at a 42 " bust and 30" waist. Sources suggest that $33 \%$ of women classified as stout during this period.

${ }^{4}$ For discussions of the slender, youthful beauty ideal and the complex values and ideas that underpinned it, see Lois Banner, American Beauty: A Social History... Through Two Centuries of The American Idea, Ideal, and Image of the Beautiful Woman (Los Angeles: Figueroa Press, 1983), 279; Caroline Evans, The Mechanical Smile: Modernism and the First Fashion Shows in France and America, 1900-1929 (New Haven: Yale University Press, 2013), 86-87; Hillel Schwartz, Never Satisfied: A Cultural History of Diets, Fantasies and Fat (New York: The Free Press, 1986), 79, 94.

${ }^{5} \mathrm{It}$ is important to note that Cary's advice existed within a broader body of advice writing directed at the stout woman which spanned everything from how to choose "flattering" dresses, to how to alter garments, to how to choose "becoming" accessories, and which could be found across regional and national fashion media. See Carmen Keist and Susan Marcketti, "The New Costumes of Odd Sizes: Plus-Sized Womens' Fashions, 19201929," Clothing and Textiles Research Journal 31, no. 4 (2013), 260.

6 This advice aligned well with fashion advice writing for women during this period, which emphasized, among other things, dress that was both modest and "visually appealing," that did not "make a spectacle" and which appealed to men while remaining inconspicuous. See Alison Matthews David, "Fashion's Chameleons: Camouflage, 'Conspicuousness,' and Gendered Display During World War I" in John Pivton, ed., The Places and Spaces of Fashion: 1800-2007 (New York: Routledge, 2009), 91.

${ }^{7}$ Cary, Style and the Woman, 10.

${ }^{8}$ Ibid., 12.

${ }^{9}$ In her writing about turn-of-the-century advice discourses, Alison Matthews David differentiates between "social camouflage," or the practice of wearing the right clothing at the right time, and "physical camouflage," or the "elements of clothing which physically affect a viewer's perception of the human body in its environment," or the "literal spaces that the clothed body inhabits."The discourses around physical camouflage were colored by the emergent science of military camouflage during World War I. See David, "Fashion's Chameleons," 91.

10 Peter Stearns, Fat History: Bodies and Beauty in the Modern West (New York: New York University Press, 1997), 54.

${ }^{11}$ Ibid., 52-54.

12 Michel Foucault, The Archaeology of Knowledge and the Discourse of Language, trans. Alan Sheridan Smith (New York: Vintage Books, [1969] 2010), 49.

${ }^{13}$ Joanne Entwistle, The Fashioned Body: Fashion, Dress and Modern Social Theory (London: Polity, 2000), 7.

${ }^{14}$ Claudia Kidwell and Margaret Christman, Suiting Everyone: The Democratization of Clothing in America (Washington, D.C.: Smithsonian Institution Press, 1976), 104. 
15 An advertisement for Oneita Union Suits published in the September 10, 1896 issue of Vogue is the earliest published clothing advertisement that invokes the word "stout" that I have been able to locate. Keist, citing a 1911 Lane Bryant article, has located a slightly later point of origin (see Carmen Keist, "How Stout Women Were Left out of High Fashion: An early twentieth-century perspective," Fashion, Style and Popular Culture 5, no. $1,25-14)$.

16 "How Many Fat Women in Your Town?" Women's Wear (June 11, 1915), 3.

17 "How Many Fat Women in Your Town," 3.

18 “Wonderland': A Coney Show: Fat Lady, Skeleton and All Moving to New York Theatre," The New York Times (January 20, 1913), 11.

19 Stearns observes that in the early twentieth-century, attacks on fat began to focus "primarily, and often very nastily, on American women," ushering in a particularly misogynist phase in America's war on fat. See Stearns, Fat History, 71.

${ }^{20}$ See, for example, "How Many Fat Women in Your Town?" 3.

21 “The Human Female Figger," Vogue (July 15, 1924), 48.

22 Winifred Aldrich, "History of Sizing Systems and Ready-to-Wear garments" in Susan Ashdown, ed., Sizing in Clothing: Developing Effective Sizing Systems for Ready-to-Wear Clothing (Cambridge: Woodhead, 2007), 2.

23 Kidwell and Christman, Suiting Everyone, 104.

${ }^{24}$ Ibid., 105.

${ }^{25}$ As Kidwell and Christman write, "Mass production meant middle quality clothing for the majority of the people, and so it was that average Americans became the best dressed average people in the world." However, such a perspective somewhat obscures the fact that new modes of policing bodies emerged as a direct result of mass manufacturing sizing being one exceptional example. See Kidwell and Christman, Suiting Everyone, 15.

${ }^{26}$ Ingrid Jeacle, "Accounting and the Construction of the Standard Body," Accounting Organizations and Society 28.1 (2003): 357-377.

${ }^{27}$ Michel Foucault, The History of Sexuality Volume I: An Introduction, trans. Robert Hurley (New York: Vintage Books, 1990), 136.

${ }^{28}$ Early stout sizing charts used the bust as the primary measurement. In published materials, the largest standard sizes were a size 40 , which corresponded with a 30 -inch waist, thereby attesting both to the narrowness of standard sizes at this point, but also to the preference for an extreme hourglass silhouette. For more on these early sizing systems see Winifred Aldrich, "History of Sizing Systems and Ready-to-Wear Garments" in Sizing in Clothing: Developing Effective Sizing Systems for Ready-to-Wear Clothing, ed. Susan Ashdown (Cambridge: Woodhead, 2007), 1-48. By turn, stout sizes typically began at a size 42. See Albert Malsin, "Scientific Specialization in Stouts," Women's Wear (July 9, 1915), 4.

${ }^{29}$ Kidwell and Christman, Suiting Everyone, 107-108.

30 "Winning the Trade of Stout Women: Manufacturer Who Specializes Says About 35 Per Cent Of Women May Be Classified As Stouts - Their Trade is Tremendously Worthwhile," Women's Wear (September 10, 1915): 5, 8. 
${ }^{31}$ Ibid.

32 “Stout Women Can Now Be Stylish,” Nerw York Times (January 14, 1917), 33.

${ }^{33}$ This statistic, while present within the media, is very difficult to verify. However, in her research, Kerry Seagrave relies upon historical actuarial height and weight tables to arrive at this estimate. Kerry Seagrave, Obesity in America, 1850-1939: A History of Social Attitudes and Treatment (Jefferson: McFarland 2008), 163-167.

${ }^{34}$ Other sources suggest that the number was closer to 5,000. See Mahoney, 50 Years of Lane Bryant, 7.

35 "Science at Last Turns its Attention to Stout People," Richmond Times-Dispatch (Sunday, April 2, 1916), 54.

${ }^{36}$ Albert Malsin, "How Science is Helping 'Stout'People to Look Less 'Stout.” Richmond Times-Dispatch (April 9, 1916), 53.

${ }^{37}$ Ibid.

${ }^{38}$ As was reported in a 1970 New York Times article, "Legend has it that a young matron asked Mrs. Bryant if she could make a functional and attractive dress for her to wear during her pregnancy - a radical idea, for in those days women did not go out or wear fashionable styles when they were pregnant. Four years later, the maternity gown with an elasticized waist was successful enough to allow Mrs. Bryant to open a checking account. Along with her checkbook, Mrs. Bryant inadvertently got a new name: a bank clerk transposed Lena into Lane, and it stuck." See Angela Taylor, "A Store That's a Haven if You're Pregnant, Tall or Plumpish,” The New York Times (April 20, 1970), 65. See also, Tom Mahoney, 50 Years of Lane Bryant (New York: Lane Bryant, 1950), 6-7.

39 “How Science is Helping 'Stout' People to Look Less 'Stout," 53.

${ }^{40}$ Ibid.

41 “To Make Stout Folk Look Thin,” Oregon Daily Journal (August 13, 1916), 48.

42 "How Science is Helping 'Stout'People to Look Less 'Stout," Richmond Times-Dispatch (April 16, 1916), 54.

${ }^{43}$ Ibid.

${ }^{44}$ Carden-Coyne and Forth have observed that the abdomen is an object of medical and scientific knowledge and a longtime target of bodily reform. Historically, this idea has materialized in women's fashions, which, with few exceptions, emphasize a slender waist. See Ana Carden-Coyne and Christopher E. Forth, "The Belly and Beyond: Body, Self, and Culture in Ancient and Modern Times" in Ana Carden-Coyne and Christopher E. Forth (eds.) Cultures of the Abdomen: Diet, Digestion, and Fat in the Modern World (New York: Palgrave MacMillian, 2005), 1-2.

${ }^{45}$ Bradley Quinn, The Fashion of Architecture (Oxford: Berg, 2003), 133.

${ }^{46}$ Mary McLeod, "Undressing Architecture: Fashion, Gender and Modernity" in Architecture: In Fashion, ed. Deborah Fausch (Princeton: Princeton Architectural Press, 1996), 39.

${ }^{47}$ Jill Fields, "Fighting the Corsetless Evil': Shaping Corsets and Culture, 1900-1930" in Beauty Business: Commerce, Gender and Culture in Modern America, ed. Philip Scranton (New York: Routledge, 2001), 113. 
48 "Making Designers: The Development of Five Years in Odd Sizes," Women's Wear (July 27, 1915), 1, 5 .

${ }^{49}$ Baum \& Wolff Inc. advertisement, The Dry Goods Economist (January 26, 1918), 84.

${ }^{50}$ See Christopher Breward, Fashion (Oxford: Oxford University Press, 2003), 32; Jennifer Craik, The Face of Fashion: Cultural Studies in Fashion (London: Routledge, 1994), 56-58; Ilya Parkins, Poiret, Dior and Schiaparelli: Fashion, Femininity and Modernity (London: Berg, 2012), 77, 123; Nancy Troy, Couture Culture: A Study in Modern Fashion (Boston: MIT Press, 2003), 6, 47.

${ }^{51}$ Elizabeth Wilson, Adorned in Dreams: Fashion and Modernity (New Brunswick: Rutgers University Press, 2003), 62.

${ }^{52}$ Carl N. Werntz, "Selling the Customer Smartness Through Basic Art Principles: No. 1. The Good and the Bad in Line," Women's Wear (June 21, 1924), 18.

${ }^{53}$ Ibid.

${ }^{54}$ The Müller-Lyer illusion dates to 1889 and is named after the psychologist who discovered it. For further discussion about the history of the illusion and the debates surrounding it, see Marjory Bates, "A Study of the Müller-Lyer Illusion, with Special Reference to Paradoxical Movement and the Effect of Attitude," The American Journal of Psychology 34.1 (January 1923), 46-72.

${ }^{55}$ Carl N. Werntz, "Selling the Customer Smartness Through Basic Art Principles: No. 5. Adapting a Model to Different Figures," Women's Wear (July 19, 1924), 14.

${ }^{56}$ Carl N. Werntz, "Selling the Customer Smartness Through Basic Art Principles: No. 6. More About the Use of an Optical Illusion,” Women's Wear (July 26, 1924), 19.

${ }^{57}$ Ibid.

${ }^{58}$ Carl N. Werntz, "Selling the Customer Smartness Through Basic Art Principles: No. 6. More About the Use of an Optical Illusion," Women's Wear (July 26, 1924), 19.

${ }^{59}$ Jane Warren Wells, Dress and Look Slender (Scranton: Personal Arts Company, 1924), iii.

${ }^{60}$ Ibid., 17.

${ }^{61}$ Ibid., 25-28.

${ }^{62}$ Malsin, "How Science is Helping 'Stout' People to Look Less 'Stout,” 53.

63 "Stout Women Can Now Be Stylish," 33.

${ }^{64}$ Keist has found isolated sources in which "extra sizes" began at a size 36. See Carmen Keist, “The New Costumes of Odd Sizes: Plus-Sized Women's Fashions, 1910-1924” (Ph.D. diss., Iowa State University, 2012), 71.

${ }^{65}$ Malsin, "Scientific Specialization in Stouts," 4.

${ }^{66}$ See, for example, "Stout Women Can Now Be Stylish," New York Times (January 14, 1917), 33.

${ }^{67}$ Malsin, "How Science is Helping 'Stout' People to Look Less 'Stout," 53.

68 "Education of Salesforce Recognized as Departmental Need," Women's Wear (February 
17, 1931), 23.

69 "Views Differ on Style in Albany," Women's Wear (October 16, 1929), 11.

70 “Diet Decimates Stouts, Dress Producer Says,” Women's Wear (May 5, 1930), 5.

${ }^{71}$ See, for instance, "Chubby Fashions on Slender Lines at Lane Bryant," Women's Wear (August 27, 1953), 3; "Chubbies Have their Own Fashion World," Women's Wear (July 10, 1957), 77; "Lane Bryant Sets Fall Style Shows," Women's Wear (August 6, 1958), 9.

${ }^{72}$ Caroline Rennolds Milbank, New York Fashion: The Evolution of American Style (New York: Harry N. Abrams, Inc.), 98-100.

${ }^{73}$ Schwartz, Never Satisfied, 191-235; Seagrave, Obesity in America, 132-138. 
Aldrich, Winifred. "History of Sizing Systems and Ready-to-Wear Garments." In Sizing in Clothing: Developing Effective Sizing Systems for Ready-toWear Clothing, edited by Susan P. Ashdown, 1-48. Cambridge: Woodhead, 2007.

Banner, Lois. American Beauty: A Social History...Through Two Centuries of the American Idea, Ideal, and Image of the Beautiful Woman. Los Angeles: Figueroa Press, 1983.

Breward, Christopher. Fashion. Oxford: Oxford University Press, 2003.

Carden-Coyne, Ana and Christopher E. Forth. "The Belly and Beyond: Body, Self, and Culture in Ancient and Modern Times." In Cultures of the Abdomen: Diet, Digestion, and Fat in the Modern World, edited by Ana Carden-Coyne and Christopher E. Forth, 1-11. New York: Palgrave MacMillan, 2005.

Cary, Marie. Style and the Woman. New York: The Textile Publishing Company, 1924.

Craik, Jennifer Craik. The Face of Fashion: Cultural Studies in Fashion. London: Routledge, 1994.

Entwistle, Joanne. The Fashioned Body: Fashion, Dress and Modern Social Theory. London: Polity, 2000.

Evans, Caroline. The Mechanical Smile: Modernism and the First Fashion Shows in France and America, 1900-1929. New Haven: Yale University Press, 2013.

Fields, Jill. "Fighting the Corsetless Evil': Shaping Corsets and Culture, 1900-1930." In Beauty Business: Commerce, Gender and Culture in Modern America, edited by Philip Scranton, 109-141. New York: Routledge, 2001.

Foucault, Michel. The Archaeology of Knowledge and the Discourse of Language, trans. Alan Sheridan Smith. New York: Vintage Books, 2010).

Foucault, Michel. The History of Sexuality Volume I: An Introduction, trans. Robert Hurley. New York: Vintage Books, 1990.

Jeacle, Ingrid. "Accounting and the Construction of the Standard Body." Accounting Organizations and Society 28, no.1 (2003): 357-377.

Keist, Carmen. "How fat women were left out of high fashion: An early twentieth-century perspective." Fashion Style and Popular Culture 5, no. 1 (2018): 25-40.

Keist, Carmen. “The New Costumes of Odd Sizes: Plus-Sized Womens' Fashions, 1910-1924.” Ph.D. diss., Iowa State University, 2012. 
Keist, Carmen and Susan Marcketti. “The New Costumes of Odd Sizes': Plus-Sized Women's Fashions, 1920-1929. Fashion and Textiles Research Journal, 31, no. 4 (2013): 259-274.

Kidwell, Claudia B. and Margaret C. Christman. Suiting Everyone: The Democratization of Clothing in America. Washington: Smithsonian Institution Press, 1974.

Mahoney, Tom. 50 Years of Lane Bryant. New York: Lane Bryant, 1950.

Matthews David, Alison. "Fashion's Chameleons: Camouflage, 'Conspicuousness,' and Gendered Display During World War I." In The Places and Spaces of Fashion: 1800-2007, edited by John Pivton, 89-106. New York: Routledge, 2009.

McLeod, Mary. "Undressing Architecture: Fashion, Gender and Modernity." In Architecture: In Fashion, edited by Deborah Fausch, 38-123. Princeton: Princeton Architectural Press, 1996.

Milbank, Caroline Rennolds. Nerw York Fashion: The Evolution of American Style. New York: Harry N. Abrams, Inc., 1989.

Parkins, Ilya. Poiret, Dior and Schiaparelli: Fashion, Femininity and Modernity. London: Berg, 2012.

Roberts, Mary Louise. Civilization Without Sexes: Reconstructing Gender in Postwar France: 1917-1927. Chicago: University of Chicago Press, 1994.

Schwartz, Hillel. Never Satisfied: A Cultural History of Diets, Fantasies and Fat. New York: The Free Press, 1986.

Seagrave, Kerry. Obesity in America, 1850-1939: A History of Social Attitudes and Treatment. Jefferson: McFarland, 2008.

Stearns, Peter. Fat History: Bodies and Beauty in the Modern West. New York: New York University Press, 1997.

Taylor, Angela. "A Store That's a Haven if You're Pregnant, Tall or Plumpish.” The New York Times (April 20, 1970), 65.

Troy, Nancy. Couture Culture: A Study in Modern Fashion. Boston: MIT Press, 2003.

Quinn, Bradley. The Fashion of Architecture. Oxford: Berg, 2003.

Wells, Jane Warren. Dress and Look Slender. Scranton: Personal Arts Company, 1924.

Wilson, Elizabeth. Adorned in Dreams: Fashion and Modernity. New Brunswick: Rutgers University Press, 2003. 


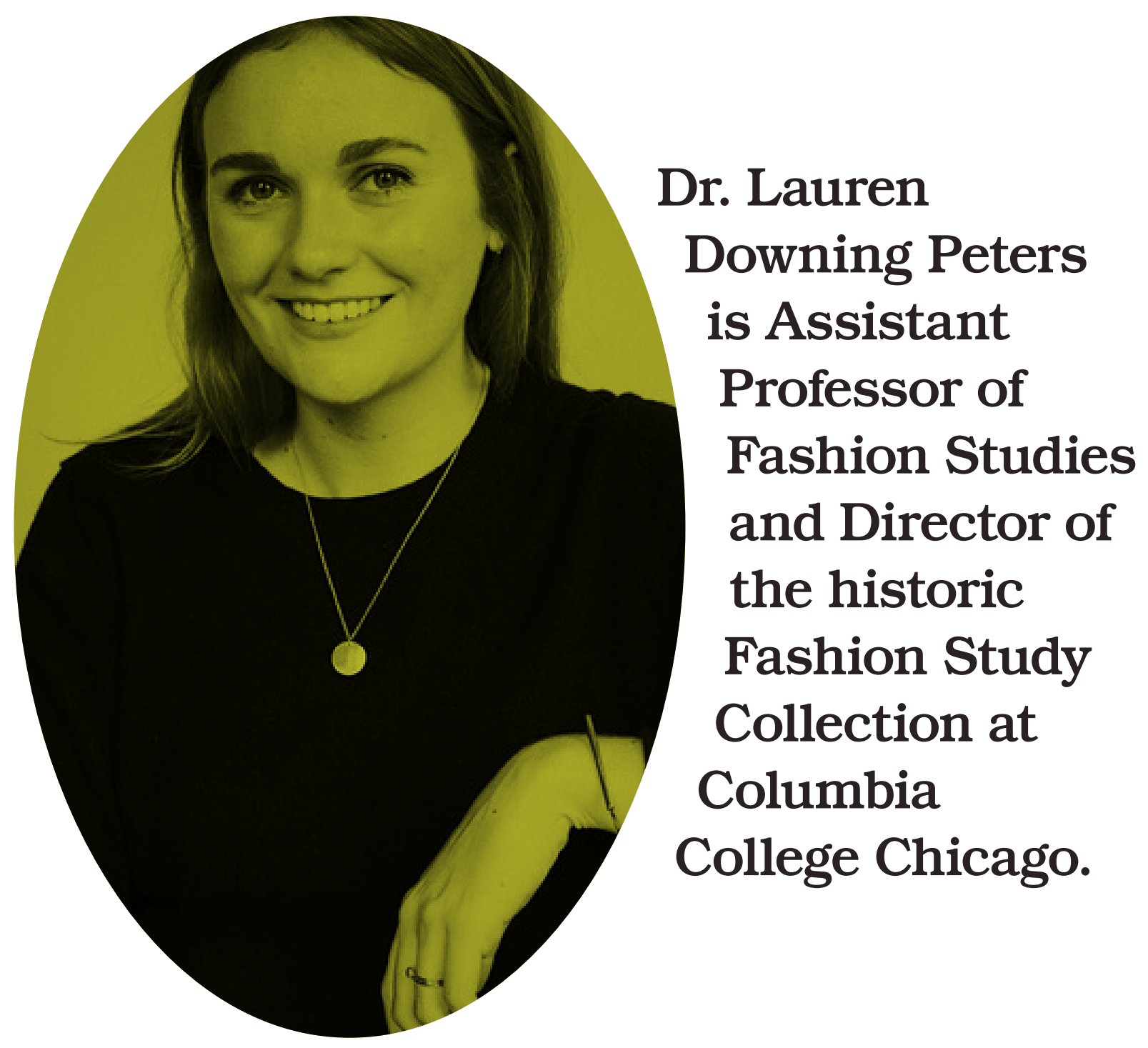

She holds a PhD in fashion studies from the Centre for Fashion Studies at Stockholm University and was among the first graduating cohort of the MA Fashion Studies program at Parsons School of Design. She is also the editor-in-chief of The Fashion Studies Journal and is a co-founding member of The Fashion Studies Alliance. Her research has been published in the peer-reviewed journals Fashion Theory, Critical Studies in Fashion And Beauty, International Journal of Fashion Studies and the Journal of Curatorial Studies, among others. She is currently working her first book manuscript, Fashioning the Flesh: Fashion, Fatness and Femininity in Early 20th Century America (Bloomsbury, 2021).

\section{ARTICLE CITATION}

Downing Peters, Lauren. "Body as Architecture: Designing the Stout Body in the Age of Standardization." Fashion Studies, vol. 3, no. 1, pp. 1-35, https://www.fashionstudies.ca/body-as-architecture, https://doi.org/10.38055/FS030101. 


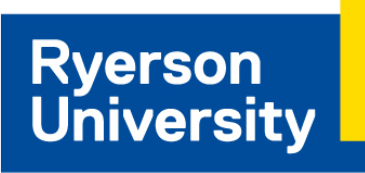

Fashion

Faculty of Communication

\& Design

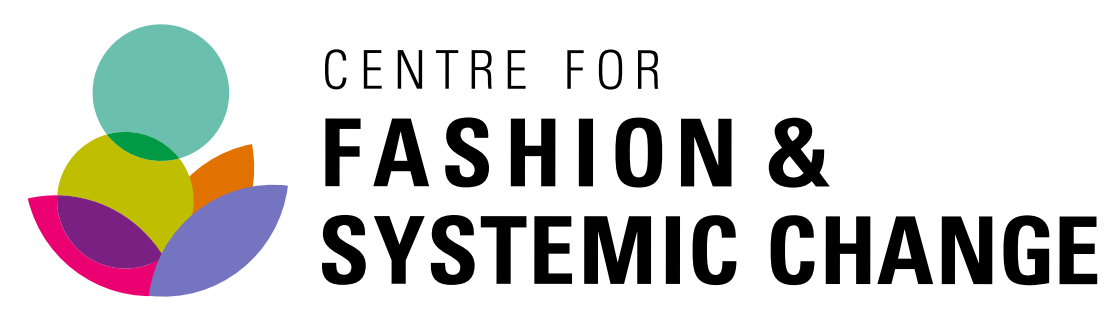

Froms SH/ON

\section{ISSN 2371-3453}

Copyright (@) 2020 Fashion Studies - All Rights Reserved

Creative Commons Attribution-NonCommercial-NoDerivatives 4.0 International (CC BYNC-ND 4.0) license (see: https://creativecommons.org/licenses/by-nc-nd/4.0/) 